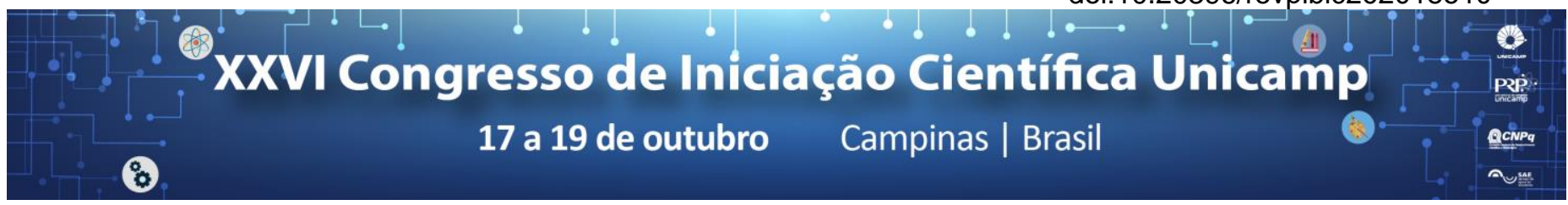

\title{
Revisão taxonômica do táxon Ophiothela (Ophiotrichidade, Ophiuroidea) com base em caracteres moleculares oriundos de duas ecorregiões do Brasil
}

\author{
Gabriela Granadier*, Renata Alitto, Michela Borges.
}

\begin{abstract}
Resumo
Este trabalho tem por objetivo o reconhecimento seguro das espécies do gênero Ophiothela oriundas de duas ecorregiões na costa brasileira. O estudo se fez necessário pois os espécimes apresentam muitas sobreposições de caracteres morfológicos e com diferentes padrões de coloração, dificultando a identificação por meio da taxonomia tradicional. Por isso, os exemplares foram estudados com base na análise do gene mitocondrial 16S. Os testes de relações filogenéticas mostraram a existência de, pelo menos, duas linhagens, porém com baixa distância genética entre elas. Estas linhagens não estão relacionadas com os diferentes padrões de coloração encontrados, ecorregiões, pontos de coleta ou substrato biológico.
\end{abstract}

\section{Palavras-chave:}

Echinodermata, DNA barcoding, genbank.

\section{Introdução}

Registrado no Brasil em 2000, o gênero Ophiothela foi tratado como invasor, provavelmente trazido por correntes marinhas ou água de lastro de navios. É um gênero com inúmeros problemas taxonômicos, onde seus caracteres morfológicos se sobrepõem e dificulta seu reconhecimento pela taxonomia tradicional. Por isso, neste trabalho, foi necessária uma revisão taxonômica com base em outra ferramenta, como a biologia molecular. Foram extraídos o DNA genômico e amplificado e sequenciado o gene mitocondrial 16S. Os exemplares são oriundos de duas ecorregiões do Brasil: I) Nordeste - Salvador (BA) e II) Sudeste: Baía do Araçá, São Sebastião (SP) e Complexo Estuarino de Paranaguá (PR).

\section{Resultados e Discussão}

Depois de fixados, os animais apresentaram coloração diversificada variando entre o roxo, rosa claro, rosa escuro e branco amarelado. Todos os espécimes foram coletados em substratos biológicos como corais ou esponjas. Estas informações foram utilizadas posteriormente para testar se havia alguma relação com as diferentes linhagens. Ao todo, 17 amostras tiveram o DNA genômico extraído e o gene mitocondrial 16S amplificado e sequenciado, sendo quatro amostras de Salvador, sete da Baía do Araçá e seis de Paranaguá. Com os dados obtidos foi confeccionada uma matriz com todas as sequências alinhadas. Para realizar os testes de relações filogenéticas, como Inferência Bayesiana (IB) e Máxima Parcimônia (MP) (Fig. 1), foram adicionadas sequências de outras espécies como Amphipholis squamata (Amphiuridae), Ophiactis simplex e Ophiactis balli (Ophiactidae), Ophiothrix angulata e Ophiothrix trindadensis (Ophiotrichidae). A IB evidenciou a presença de três clados fortemente suportados, chamados de Clado A (Ophiothela sp.), Clado B (Ophiothrix sp.) e Clado C (Ophiactis sp.). Dentro do Clado A, foram identificados dois clados nomeados de D e E. A MP evidenciou apenas três clados, sendo A (Ophiothela sp.), B (Ophiothrix sp.) e C (Ophiactis sp.). As distâncias genéticas estimadas por cirtério $p$-distance entre o Clado A (Ophiothela sp.) e B (Ophiothrix sp) foi $21 \%$, Clado A (Ophiothela sp.) e C (Ophiactis sp.) foi $29 \%$. Dentro do Clado $A$ as distâncias variaram de 0 a $2 \%$. De acordo com os índices comumente usados para ofiuróides na delimitação de espécies ${ }^{1}$, as distâncias genéticas dentro do Clado A significam variação intraespecífica.

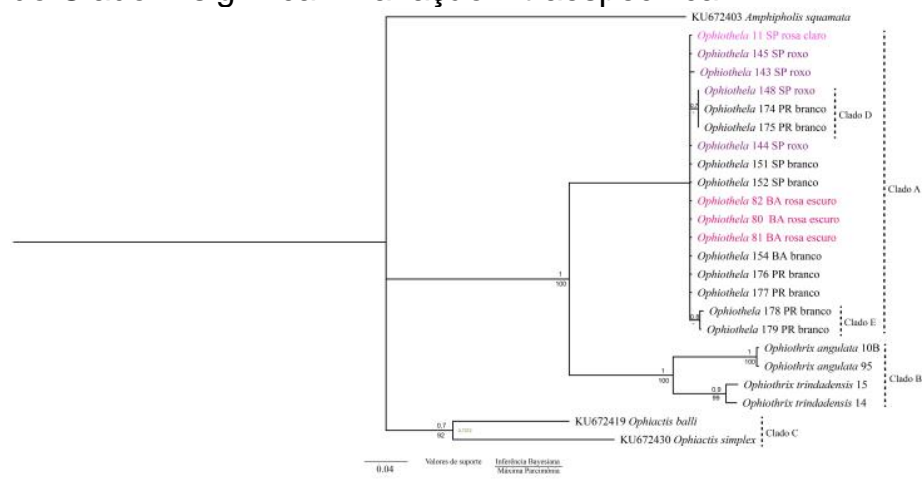

Figura 1. Reconstrução filogenética do gene $16 \mathrm{~S}$ para Ophiothela obtida por Inferência Bayesiana. Os números dos nós representam os valores de suporte para Inferência Bayesiana (em cima) e Máxima Parcimônia (em baixo). As cores indicadas se referem aos espécimes depois de fixados. Os ramos estão identificados pelos números das amostras e suas localidades (BA = Bahia; $\mathrm{SP}=\mathrm{São}$ Paulo; $\mathrm{PR}=$ Paraná). $\mathrm{A}$ barra de escala representa as substituições de nucleotídeos médias por local. $O$ traço (-) indica que o ramo não foi indicado na análise de Máxima Parcimônia.

\section{Conclusões}

Os exemplares de Ophiothela sp. apresentaram, pelo menos, duas linhagens, as quais não estão relacionadas com a cor, localidade, pontos de coleta ou substrato biológico. Desta forma, estão sendo realizados mais estudos para corroborar os resultados. Utilizando a análise de caracteres morfológicos internos (vértebras e placas braquiais) por meio de Microscopia Eletrônica de Varredura. Estes estudos têm sido considerados consistentes para a taxonomia, especialmente quando integrado a dados moleculares.

\section{Agradecimentos}

FAPESP (Processo o 2017/09987-3). CAPES PDSE (Processo 88881.131940/2016-01). Karin R. Seger e Profá. Luciana B. Lourenço por disponibilizarem o LABESC para a realização deste trabalho.

\footnotetext{
${ }^{1}$ Pérez-Portela, R.; Almada, V.; Turon, X. Cryptic speciation and genetic structure of widely distributed brittle stars (Ophiuroidea) in Europe. Zoologica Scripta. 2012. Vol. 42, No. 2, 151-169.
} 